US Army Corps of Engineers $_{\circledast}$

\title{
Evaluation of Remotely Sensed Data for the Application of Geospatial Techniques to Assess Hurricane Impacts on Coastal Bird Habitat
}

by Sam S. Jackson, Richard A. Fischer, Michael P. Guilfoyle, and James S. Wakeley

PURPOSE: The 2004 hurricane season significantly impacted portions of Florida's coastlines and altered shoreline habitat for a wide variety of coastal organisms (Greening et al. 2006). Remotely sensed data can help characterize and assess these habitats and provide inferences on how hurricanes and subsequent coastal engineering practices affect the distribution and abundance of these species. This technical note focuses specifically on providing a better understanding of the requirements and limitations involved for mapping coastal bird habitat with respect to hurricane impacts. Recommendations are also made for conducting surveys to effectively monitor shoreline-dependent bird communities, since the geospatial data are specifically intended to supplement this effort.

BACKGROUND: On 13 October 2004, President George W. Bush signed into law the Military Construction Appropriations and Emergency Hurricane Supplemental Appropriations Act of 2005 (Public Law 108-324), which authorized the Shore Protection Project Performance Improvement Initiative (S3P2I), or simply Shore Protection Assessment (SPA), in direct response to the 2004 hurricane season that had such an impact on portions of Florida. This document is a product of the Environmental Consideration work unit funded under this Initiative.

To appropriately assess the impact hurricanes have on coastal bird habitats, it is necessary to obtain suitable pre- and post-storm data on the distribution, abundance, and structure of these habitats. This allows for the establishment of baseline data (pre-conditions) that can then be compared to post-event data to assess the amount of change that occurred. It is also necessary to acquire data on the distribution and abundance of shoreline-dependent birds from discrete coastal locations that coincide with the remotely sensed data.

Due to the lack of sufficient pre-storm remotely sensed data, the focus of the effort was redirected to conducting a "proof of concept" approach using only the more suitable post-event data. This research effort involved the gathering and evaluation of remotely sensed data (with assessment of post-event data) and suggests an approach for directly measuring habitat changes before and after future storm events.

STUDY AREA: The study area is in Lee County, FL from just south of Captiva Pass (R66 ${ }^{1}$ ) extending to Sanibel Island/San Carlos Bay (R174) (see Figure 1). The focus area for this effort is approximately 22 miles of mainland and island coastline located just a few miles south of the

\footnotetext{
${ }^{1}$ Range Monument ID. Source: Florida Department of Environmental Protection.
} 
point where Hurricane Charley made landfall on 13 August 2004. This particular stretch of shoreline provides numerous sites with quality habitat for shoreline-dependent birds as well as available data on bird distribution and abundance prior to the 2004 hurricane season. In addition, Lee County actively participates in a beach management program for restoration and renourishment of their beaches. Neal (2005) documented that beaches eroded as much as $100 \mathrm{ft}$ in some places, while other areas showed accretion, following Hurricane Charley.

The Lee County study site was selected for the following reasons:

1) The southwest coast of Florida, including coastal areas in Lee County, has established habitat for numerous shoreline-dependent birds.

2) Pre- and post-hurricane coastal bird community data were and will continue to be collected by the National Audubon Society and the Florida Fish and Wildife Conservation Commission.

3) The barrier islands in that area have a good mix of shoreline areas subjected to federal shore protection projects and conservation areas that have received little or no shore protection efforts.

4) The area was hit directly by Hurricane Charley in 2004 (Figure 1).

PROOF OF CONCEPTIEVALUATION: High-resolution imagery is currently a widely-used and practical form of remote sensing that, when combined with LiDAR, can be effectively used to map shoreline habitat. The authors searched extensively for suitable remotely-sensed prehurricane data for Lee County, FL. Although imagery of marginal quality was located for portions of Lee County, much of it covered portions of urban areas near Fort Meyers (not in the study area), had a high horizontal error and/or coarse spatial resolution, and/or was not collected simultaneously with the LiDAR data (or within an acceptable timeframe). Table 1 summarizes pre- and post event data that were evaluated for Lee County, FL, and its associated suitability.

\section{Table 1. Summary of Remotely-Sensed Pre-Hurricane 2004 Data and Post-Hurricane 2005 and 2006 Data for Lee County, FL.}

\begin{tabular}{||l|l||}
\hline \hline Pre-Hurricane Data & Suitability \\
\hline SHOALS Data, June 2004, LiDAR and imagery & High horizontal error (image), not sufficient for detailed analysis \\
\hline Lee Co., April 2002, Digital Orthophotography & Collected two years before Hurricane Charley, too much change \\
\hline Lee Co., July 2004, Digital Orthophotography & Only covers urban area of Lee Co., no bird habitat coverage \\
\hline Quickbird, March 2004, Satellite imagery & Only covers small portion of beach/variable collection dates/conditions \\
\hline IRS, April-May 2004, Satellite imagery & Inadequate spatial resolution (5 m), high cost \\
\hline Post-Hurricane Data & \\
\hline SHOALS Data, November 2004, LiDAR and imagery & High horizontal error (image), not sufficient for detailed analysis \\
\hline CHARTS Data, June 2006, LiDAR/CASI imagery & High accuracy, within timeframe. Used for post-analysis \\
\hline Lee Co., January 2005, Digital Orthophotography & High accuracy, post hurricane, pre-engineering activities \\
\hline
\end{tabular}




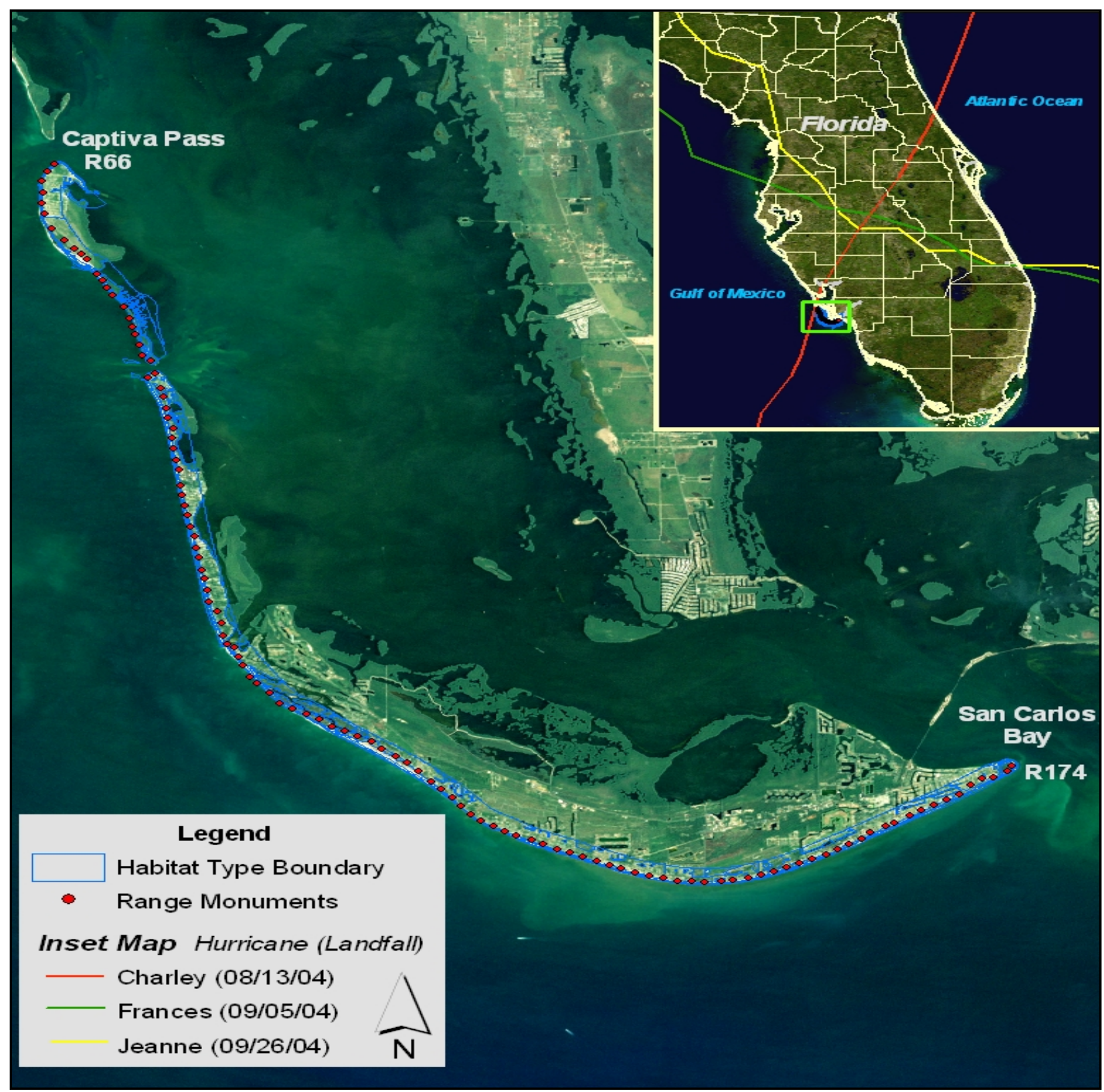

Figure 1. Location of study area in Lee County, Florida, from Captiva Pass (R66) to San Carlos Bay (R174).

In late 2006, high-accuracy, high-resolution hyperspectral imagery and airborne bathymetric LiDAR data were obtained from the U.S. Army Corps of Engineer's Joint Airborne LiDAR Bathymetry Technical Center of Expertise (JALBTCX). This dataset was used to perform the post-storm (proof of concept) assessment and was not available prior to Hurricane Charley. The Data were collected on June 8, 2006 using JALBTCX's in-house survey capability Compact Hydrographic Airborne Rapid Total Survey (CHARTS) system. The system components include an Optech, Inc., SHOALS-3000 LiDAR instrument integrated with an Itres CASI-1500 hyperspectral imager (http://shoals.sam.usace.army.mil/). CHARTS collects the LiDAR data at $3 \mathrm{kHz}$ concurrent with the hyperspectral imagery $(0.5-\mathrm{m}$ resolution). The bathymetric LiDAR 
data were acquired at a flying altitude of approximately $400 \mathrm{~m}$. Data were collected as part of another project that encompassed the study area and were readily available for analysis. The primary benefit of using the hyperspectral imagery instead of the true color (rgb) imagery, which can also be collected with CHARTS, was the higher horizontal accuracy (when compared to other available data) and the additional spectral analysis that could be performed if desired. However, the primary purpose of the imagery for this analysis was for visual interpretation and delineation of habitat classes.

The CHARTS bathymetric LiDAR data used for this analysis generally cover an area of approximately $1000 \mathrm{~m}$ offshore (bathymetric) and $500 \mathrm{~m}$ inland (topographic) of the Gulf shoreline, although the coverage varies slightly by survey. A slightly reduced LiDAR coverage area of $900 \mathrm{~m}$ offshore and $450 \mathrm{~m}$ inland was available for the Lee County shoreline, which dictated the area chosen for performing the habitat classification. Within this area, seven major coastal habitat types were identified for potential use by shoreline-dependent birds (Table 2) and created habitat polygons for each in Environmental Systems Research Institute (ESRI) ArcGIS 9.0. These coastal habitats included:

1) Emergent offshore shoals

2) Intertidal beach (based on highly variable low and high tides)

3) Dry beach

4) Dunes with no vegetation or sparse vegetation ( $<30 \%$ cover $)$

5) Vegetated dunes ( $\geq 30 \%$ vegetation)

6) Upland vegetation (all vegetation inland of sandy dunes)

7) Any type of human development (buildings, roads, etc.)

8) Inland water (including lagoons/bays).

Habitat types were interpreted at a mapping scale of 1:2000. Emergent offshore shoals and intertidal beach habitat availability vary by tide level, so polygons were created at elevations representative of both high and low tide to discriminate exposed areas (accessible to birds) above the water's surface during varying tidal conditions. The mixed semi-diurnal tides (two unequal high and low tides) typical of this area constituted the intertidal beach areas. These two habitat types were delineated using a combination of tide elevation data (local gauge), LiDAR, and imagery, whereas the remaining types were visually interpreted solely from the imagery. Since intertidal habitats along barrier islands and mainland shores (including inlets) are particularly important for birds during all seasons (Evans and Dugan 1984, Harrington 2008, Lott et al., in preparation), efforts should be made to identify, map, and monitor these habitats for birds.

Local tide gauge data (Naples gauge) were downloaded from NOAA for May 2006 through July 2006, which coincided with the LiDAR collection date (http://tidesandcurrents.noaa.gov/). The Naples gauge was not operating for a portion of this time period, so a comparison was made between the predicted and observed tides (collected when the gauge was operating), and the differences were insignificant. Therefore, the predicted values were used for the calculations. Tide elevations representing Lowest Low Water (LLW), Lowest High Water (LHW), and Highest High Water (HHW) were manually selected for each day during the time period and were obtained for each of the tide levels during the same time period. When the tide is at LLW, the greatest amount of intertidal habitat will be exposed and at HHW the least amount of intertidal 


\begin{tabular}{|c|c|c|c|}
\hline Habitat Type & $\begin{array}{l}\text { Important Species } \\
\text { using Habitat Type }\end{array}$ & $\begin{array}{l}\text { Seasonal } \\
\text { Importance }\end{array}$ & Description \\
\hline $\begin{array}{l}\text { Emergent } \\
\text { Offshore } \\
\text { Shoals }\end{array}$ & $\begin{array}{l}\text { Seabirds (e.g., Greater } \\
\text { Shearwater, Puffinus } \\
\text { gravis) }\end{array}$ & $\begin{array}{l}\text { Breeding, } \\
\text { Migration }\end{array}$ & $\begin{array}{l}\text { Any OFFSHORE area of sand or mud that is exposed above } \\
\text { the water's surface level at some point during the tidal cycle } \\
\text { and submerged during the rest of the tidal cycle }\end{array}$ \\
\hline $\begin{array}{l}\text { Intertidal } \\
\text { Beach }\end{array}$ & $\begin{array}{l}\text { Shorebirds and Wading } \\
\text { Birds (e.g., Snowy Plover } \\
\text { and Reddish Egret) }\end{array}$ & $\begin{array}{l}\text { All- } \\
\text { especially for } \\
\text { foraging }\end{array}$ & $\begin{array}{l}\text { Any ONSHORE area of sand or mud that is exposed above the } \\
\text { water's surface level at some point during the tidal cycle and } \\
\text { submerged during the rest of the tidal cycle }\end{array}$ \\
\hline Dry Beach & $\begin{array}{l}\text { Shorebirds (e.g., Snowy } \\
\text { Plover, Piping Plover) }\end{array}$ & $\begin{array}{l}\text { Breeding, } \\
\text { Wintering }\end{array}$ & $\begin{array}{l}\text { Gradually sloping area of sand that is generally dry and stays } \\
\text { exposed to the air throughout the entire tidal cycle. This area is } \\
\text { only submerged during storms or extreme high tides. The only } \\
\text { topographic relief on the dry beach is where storms or high } \\
\text { tides have eroded scarps into the beach. The dry beach } \\
\text { generally has a gradual slope, a steep scarp, and then another } \\
\text { gradual slope before merging with either the dune or developed } \\
\text { area. }\end{array}$ \\
\hline $\begin{array}{l}\text { Nonvegetated } \\
\text { Dunes }\end{array}$ & $\begin{array}{l}\text { Shorebirds (e.g., Wilson's } \\
\text { Plover, Red Knot) }\end{array}$ & $\begin{array}{l}\text { Breeding, } \\
\text { Migration }\end{array}$ & $\begin{array}{l}\text { The area of dry sand that is landward of the gentle sloping dry } \\
\text { beach with variable and irregular topographic relief. Not all } \\
\text { beaches within the study area have dunes and in some cases } \\
\text { the dry beach transitions directly into the developed area. } \\
\text { Unvegetated dunes have bare sand and have very little, }<30 \% \text {, } \\
\text { or no vegetation) }\end{array}$ \\
\hline $\begin{array}{l}\text { Vegetated } \\
\text { Dunes }\end{array}$ & $\begin{array}{l}\text { Shorebirds (e.g., Red } \\
\text { Knot) }\end{array}$ & Migration & $\begin{array}{l}\text { Same description as above, except vegetated dunes have } \\
\text { significant vegetation- grass, forbs, or shrubs comprising } \geq 30 \% \\
\text { of the dune. }\end{array}$ \\
\hline $\begin{array}{l}\text { Upland } \\
\text { Vegetation }\end{array}$ & $\begin{array}{l}\text { Wading Birds (e.g., } \\
\text { Black-crowned Night } \\
\text { Heron, Nycticorax } \\
\text { nycticorax) }\end{array}$ & $\begin{array}{l}\text { Breeding, } \\
\text { Migration }\end{array}$ & $\begin{array}{l}\text { Any terrestrial vegetation that occurs landward of the dune. The } \\
\text { transition between sparse dune vegetation and more dense and } \\
\text { higher terrestrial vegetation are obvious from the imagery. }\end{array}$ \\
\hline $\begin{array}{l}\text { Developed } \\
\text { Areas }\end{array}$ & $\begin{array}{l}\text { Seabirds (e.g., Ring- } \\
\text { billed Gull, Larus } \\
\text { delawarensis) }\end{array}$ & Breeding & $\begin{array}{l}\text { Any upland area with roads, buildings, parking lots, or other } \\
\text { type of development }\end{array}$ \\
\hline Inland Waters & $\begin{array}{l}\text { Wading Birds and } \\
\text { Shorebirds (e.g., Great } \\
\text { Blue Heron, Ardea } \\
\text { herodias, and Spotted } \\
\text { Sandpiper, Actitis } \\
\text { macularia) }\end{array}$ & All & Inland freshwater bodies, bays and lagoons \\
\hline
\end{tabular}

habitat will be exposed. Very few of the low water elevations were present in the LiDAR data. This was due to lack of hard bottom signal returns from the laser beam, primarily because of poor water clarity or lack of penetration through the surf zone when tide levels may have been higher during data acquisition. The ideal time to fly the coastline for LiDAR data acquisition is at the lowest tide possible to have better reflectance from hard-surface returns; however, signal returns in the lower intertidal area (LLW to LHW)/upper surf zone may still not be possible. Because of the limited data values, a range of values representing each of the tide levels (where LiDAR returns were not available) were selected from the tide gauge data and subsequently extracted from the LiDAR data in an attempt to delineate the intertidal habitat area. In most cases, however, sufficient LiDAR returns were still not present for extreme low-tide levels. If adequate returns were available, this portion of the intertidal area was interpolated using the very limited LiDAR points. See Figure 2 for a representation of the delineated habitat types. 


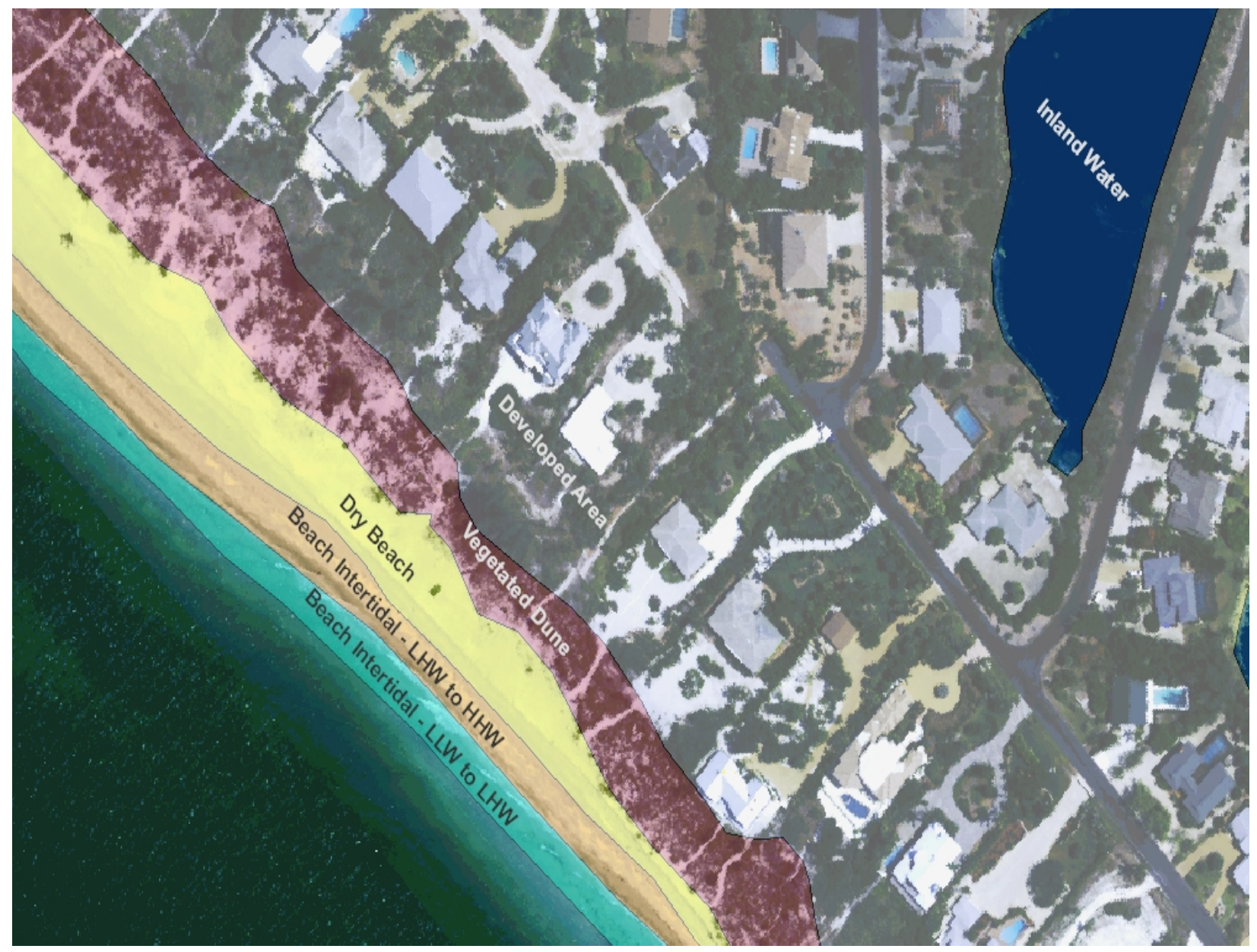

Figure 2. Example of habitat type delineation, Lee County, FL; delineations are made using a combination of available tide elevation data, LiDAR, and imagery.

DISCUSSION and RECOMMENDATIONS: The intent of this project was to obtain suitable pre- and post-hurricane imagery and LiDAR data to conduct the desired analyses. Unfortunately, prior to the 2004 hurricane season, the only comprehensive efforts being made to collect reliable coastal imagery in Florida were either not within the desired timeframe (collected two years prior) or were not suitable for the intended analysis. One such image dataset that was obtained to evaluate the pre-storm conditions (SHOALS rgb imagery, June 2004) was not suitable for this type of detailed habitat analysis because of the high horizontal error between the mosaicked image tiles. The imagery was collected with a non-metric camera and likewise does not result in calibrated, geometrically correct images. Horizontally accurate habitat mapping cannot be performed with this imagery when digitizing at the desired mapping scale (1:2000) and therefore was not considered suitable pre-storm image data.

Although the SHOALS LiDAR system is a bathymetric scanner that has the capability to penetrate water, turbid water and/or breaking waves in the surf zone may at times prevent adequate signal returns, as experienced with this collection. The primary habitat used by shoreline birds (for foraging) and where many bird observation counts are made is within the lower intertidal area between LLW and LHW, which is within the near-shore portion of the surf 
zone. This transitional tidal zone had very limited LiDAR returns and thus prevented habitat mapping of pre-storm conditions (within this area) as well as much of the post-storm area/conditions.

Because the CHARTS data used for this analysis was intended for another application, clear water conditions or the ability to penetrate the surf zone (to enable subsequent mapping of the intertidal area) was not a requirement and therefore was not considered in the operational planning of the flight. However, there are several things that can be done to reduce the possibility of insufficient signal returns and improve returns in the intertidal area. New techniques are being developed that will employ an improved scan pattern, one that is capable of generating more points, thus improving the possibility of signal returns within the surf zone. Lacking this capability, it is wise to allow adequate operational planning time to avoid conditions when the water is very turbid and flights should always be done at the lowest tide possible. Following these procedures will hopefully result in sufficient LiDAR returns in the intertidal area so that the appropriate bird habitat can be mapped and monitored over time. County-wide flights along coastal areas should be scheduled at least every three years, preferably at more frequent intervals. Imagery and LiDAR data, collected simultaneously, can be archived and made available to research organizations for numerous future research applications.

Collaboration between the Corps and state and local agencies will help facilitate the regular collection of coastal imagery and LiDAR data that will permit further understanding of hurricane impacts on coastal resources and coastal bird communities. It is anticipated that the information contained within this technical note will help improve collection efforts (of appropriate imagery and LiDAR data) and seasonal bird community data necessary to test and evaluate changes in coastal habitats due to shore protection projects and storm events.

An approach for performing a geospatial analysis using LiDAR data and imagery for monitoring coastal bird habitats with respect to hurricane impacts is summarized below. Since this approach is directly intended to supplement the assessment of coastal birds and their habitat, surveying methods for monitoring shoreline-dependent bird communities are included.

\section{Geospatial Analysis using LiDAR data and Imagery:}

1) Collect high-resolution imagery along the coastline at regular intervals (at least every three years, but annually if possible). Hyperspectral imagery can be used to perform additional spectral analysis that is not possible with true color imagery (digital orthophotos) or multispectral imagery, but usually comes at a much higher cost. Due to its availability and higher horizontal accuracy, the hyperspectral imagery for this study was used to delineate coastal habitats. No additional spectral analyses were performed. However, any high-resolution, high-accuracy image product could be used as long as preand post-conditions are captured with an equivalent image product and the collection was concurrent with the LiDAR acquisition. Frequent collection intervals are recommended to detect impacts of future storm events and to differentiate storm events from normal erosion processes.

2) Collect high-resolution airborne bathymetric LiDAR data concurrent with the imagery. Data should be collected at a flying altitude of approximately $400 \mathrm{~m}$. 
3) For Corps Districts, data collection can be coordinated with the U.S. Army Corps of Engineer's Joint Airborne LiDAR Bathymetry Technical Center of Expertise (JALBTCX).

4) Data should be acquired at the lowest tide possible so elevations can be extracted from the LiDAR data representing Lowest Low Water (LLW), Lowest High Water (LHW), and Highest High Water (HHW). Local tide gauge data from NOAA can be used to determine corresponding elevations for tide levels representing each intertidal area important for bird habitat. In cases where few LiDAR returns are available, a range of values representative of the variable intertidal areas will need to be used.

5) Data should then be incorporated into Geographic Information System (GIS) software for habitat delineation (see Table 2 for a list of important habitats for shoreline-dependent bird communities).

6) Data should be archived to assess changes in habitat availability over time and to evaluate impacts of habitat changes on seasonal shoreline-dependent bird communities; archived data can also be made available to numerous research organizations conducting coastal research.

\section{Survey Methods for Monitoring Shoreline-dependent Bird Communities:}

1) Continue to identify coastal habitats important to local and regional shoreline-dependent bird communities for Florida, as well as the entire Gulf Coast; focus on identifying critical intertidal areas known to be important to breeding, roosting, and foraging shoreline-dependent birds, particularly low-energy bay intertidal flats, bay beaches and adjacent shallow water areas, flood shoals, mudflats, and inlet shorelines (Harrington 2008; Lott et al., in preparation).

2) Establish monitoring stations at selected sites; use standardized ground-based survey protocols during the breeding season as described by Steinkamp et al. (2003) and during the wintering migratory seasons as described by Howe et al. (2000). Additional nonbreeding survey wetland bird survey methods can be obtained through the British Ornithology Trust (BTO) at http://www.bto.org/webs/index.htm (Lott et al., in preparation).

3) Standardized survey methods that include detectability estimates, particularly during the breeding season, are recommended for implementation on all Corps project lands for population trend estimation (Guilfoyle and Fischer 2007).

4) During surveys, data collected should include number and species of birds observed, plus additional information pertinent to understanding impacts of hurricanes and shoreline protection projects on coastal birds, including tide conditions, local observable disturbance sources, habitat conditions, behavior (nesting, foraging, roosting), habitat substrate (e.g., intertidal sand, mud, dry beach, old wrack), and habitat type (e.g., inlet shoreline, bayside beach, mudflat) (Lott et al., in preparation). A sample data sheet and description of fall migration survey methods used during surveys in Lee County, FL, can be found in Lott et al. (in preparation). 
ACKNOWLEDGMENTS: Research conducted for this technical note was funded by the Shore Protection Assessment Program. The Technical Director of the program at the time of publication was Dr. Jack E. Davis and the Program Manager was William R. Curtis. The work was performed under the direction of Dr. William Martin, Director of the Coastal and Hydraulics Laboratory (CHL), U.S. Army Engineer Research and Development Center (ERDC). The authors would like to thank the following for their support regarding this project: Dr. Steven L. Ashby, Principal Investigator for the Environmental Consideration Work Unit (EL), Mark R. Graves (EL), Jeff Lillycrop and Jennifer Wozencraft of the JALBTCX for supplying the data and assisting in product development, and Casey Lott of American Bird Conservancy. At the time of publication, Director of EL was Dr. Beth Fleming and Chief of EE was Ed Russo. Dr. James R. Houston was Director of ERDC, and COL Gary E. Johnston was Commander.

POINTS OF CONTACT: For additional information, contact Sam S. Jackson, U.S. Army Engineer Research and Development Center (ERDC), Vicksburg, MS (601-634-3317, Sam.S.Jackson@usace.army.mil). This technical note was written by Mr. Jackson and Drs. Richard Fischer, Michael Guilfoyle, and James Wakeley, ERDC-EL. This document should be cited as follows:

Jackson, S. S., R. A. Fischer, M. P. Guilfoyle, and J. S. Wakeley. 2009. Evaluation of remotely sensed data for the application of geospatial techniques to assess hurricane impacts on coastal bird habitat. ERDC/EL TN-09-1. Vicksburg, MS: U.S. Army Engineer Research and Development Center. http://el.erdc.usace. army.mil/.

\section{REFERENCES}

Evans, P. R., and P. J. Dugan. 1984. Coastal birds: Numbers in relation to food resources. In Coastal Waders and Wildfowl in Winter, ed. P. R. Evans, J. D. Goss-Custard, and W. G. Hale. Cambridge, UK: Cambridge University Press.

Greening, H., P. Doering, and C. Corbett. 2006. Hurricane impacts on coastal ecosystems. Estuaries and Coasts 29:877-879.

Guilfoyle, M. P., and R. A. Fischer. 2007. Implementing avian inventory and monitoring efforts on Corps of Engineers project lands. EMRRP Technical Notes Collection. ERDC TN-EMRRP-SI-32. Vicksburg, MS: U.S. Army Engineer Research and Development Center. www.wes.army.mil/el/emrrp.

Harrington, B. 2008. Coastal inlets as strategic habitat for shorebirds in the southeastern United States. DOER Technical Notes Collection. ERDC/TN DOER-E25. Vicksburg, MS: U.S. Army Engineer Research and Development Center.

Howe, M., J. Bart, S. Brown, C. Elphick, R. Gill, B. Harrington, C. Hickey, G. Morrison, S. Skagen, and N. Warnock, eds. 2000. A comprehensive monitoring program for North American shorebirds. Manomet, MA: Manomet Center for Conservation Sciences. http://www.fws.gov/shorebirdplan/USShorebird/downloads/MONITOR3.doc 
Lott, C. A., C. S. Ewell, and K. L. Volansky. Habitat associations of shoreline-dependent birds in barrier island ecosystems during fall migration in Lee County, Florida. In preparation. Vicksburg, MS: U.S. Army Engineer Research and Development Center.

Neal, R. 2005. Impacts of Hurricane Charley on the Southwest Florida Coastline, Focusing on Lee County. Florida Beach and Preservation Association's National Conference on Beach Preservation Technology, Destin, FL, 2-4 February 2005.

Steinkamp, M, Peterjohn, B., Byrd, V., Carter, H., and Lowe, R. 2003. Breeding season survey techniques for seabirds and colonial waterbirds throughout North America. Laurel, MD: Waterbird Monitoring Partnership, U.S. Geological Survey, Patuxent Wildlife Research Center.

http://www.pwrc.usgs.gov/cwb/manual/.

NOTE: The contents of this technical note are not to be used for advertising, publication, or promotional purposes. Citation of trade names does not constitute an official endorsement or approval of the use of such products. 